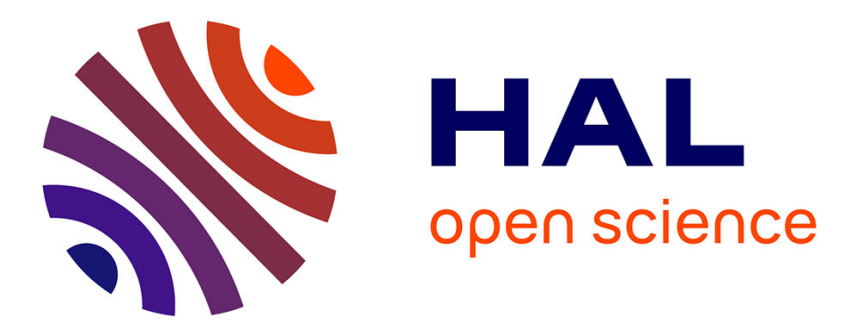

\title{
Invasiveness of an introduced species: the role of hybridization and ecological constraints
}

Émilien Luquet, Christoph Vorburger, Frédéric Hervant, Pierre Joly, Bernard Kaufmann, Dirk S. Schmeller, Jean-Paul Léna, Odile Grolet, Lara Konecny, Sandrine Plénet

\section{To cite this version:}

Émilien Luquet, Christoph Vorburger, Frédéric Hervant, Pierre Joly, Bernard Kaufmann, et al.. Invasiveness of an introduced species: the role of hybridization and ecological constraints. Biological Invasions, 2011, 13 (8), pp.1901-1915. 10.1007/S10530-011-0010-2 . halsde-00641392

\section{HAL Id: halsde-00641392 \\ https://hal.science/halsde-00641392}

Submitted on 31 Jan 2019

HAL is a multi-disciplinary open access archive for the deposit and dissemination of scientific research documents, whether they are published or not. The documents may come from teaching and research institutions in France or abroad, or from public or private research centers.
L'archive ouverte pluridisciplinaire HAL, est destinée au dépôt et à la diffusion de documents scientifiques de niveau recherche, publiés ou non, émanant des établissements d'enseignement et de recherche français ou étrangers, des laboratoires publics ou privés. 


\title{
Invasiveness of an introduced species: the role of hybridization and ecological constraints
}

\author{
E. Luquet $\cdot$ C. Vorburger $\cdot$ F. Hervant $\cdot$ \\ P. Joly • B. Kaufmann • D. S. Schmeller • \\ J. P. Léna · O. Grolet • L. Konecny · S. Plénet
}

\begin{abstract}
Introduced species are confronted with new environments to which they need to adapt. However, the ecological success of an introduced species is generally difficult to predict, especially when hybridizations may be involved in the invasion success. In western Europe, the lake frog Pelophylax ridibundus appears to be particularly successful. A reason for this species' success might be the presence of the invader's genetic material prior to the introduction in the form of a hybrid between $P$. ridibundus and a second indigenous water frog species. These hybrids reproduce by hybridogenesis, only transmitting the ridibundus genome to gametes and backcrossing with the indigenous species (i.e. P. lessonae). This reproductive system allows the hybrid to be independent
\end{abstract}

E. Luquet $(\bowtie) \cdot$ F. Hervant $\cdot$ P. Joly $\cdot$ B. Kaufmann . J. P. Léna · O. Grolet · L. Konecny · S. Plénet CNRS, UMR5023 Ecologie des Hydrosystèmes Naturels et Anthropisés, Villeurbanne 69622, France e-mail: emilien.luquet@gmail.com

C. Vorburger

Institute of Integrative Biology, ETH Zürich, 8092 Zürich, Switzerland

C. Vorburger

EAWAG, Swiss Federal Institute of Aquatic Science and Technology, Überlandstrasse 133, 8600 Dübendorf,

Switzerland

D. S. Schmeller

Station d'Ecologie Experimentale du CNRS à Moulis, 09200 Saint Girons, France from $P$. ridibundus, and allows the ridibundus genome to be more widely spread than the species itself. Matings among hybrids produce newly formed $P$. ridibundus offspring $(\mathrm{N})$, if the genomes are compatible. Therefore, we hypothesize that hybridogenesis increases the invasiveness of $P$. ridibundus (1) by enhancing propagule pressure through $\mathrm{N}$ individuals, and/or (2) by increasing adaptation of invaders to the native water frogs' habitat through hybrid-derived ridibundus genomes that are locally adapted. We find support for the first hypothesis because a notable fraction of $\mathrm{N}$ tadpoles is viable. However, in our seminatural experiments they did not outperform ridibun$d u s$ tadpoles in the native water frogs' habitat, nor did they differ physiologically. This does not support the second hypothesis and highlights ecological constraints on the invasion. However, we cannot rule out that these constraints may fall with ongoing selection, making a replacement of indigenous species highly probable in the future.

Keywords Water frogs - Hybridogenesis . Propagule pressure - Local adaptation . Ecophysiological tolerance $\cdot$ Larval performance

\section{Introduction}

Research on biological invasions focuses on two main topics: the potential of species to become invasive (i.e. 
invasiveness), and the susceptibility of native communities and habitats to invasion (i.e. invasibility) (Alpert et al. 2000; Kolar and Lodge 2001; Sakai et al. 2001). So far, this research agenda was unable to clearly define characters for species invasiveness or community invasibility (Facon et al. 2006). Although some successful invaders may be "pre-adapted" to exploit their new environment, most invaders evolve in response to the new selective regime of the invaded habitat (Ellstrand and Schierenbeck 2000; Lee 2002; Facon et al. 2006; Suarez and Tsutsui 2008). This may have hampered the predictability of biological invasions. A general eco-evolutionary framework may improve our understanding of biological invasions. Two general patterns have emerged from several studies: invasions tend to be facilitated by high propagule pressure (Lockwood et al. 2005) and by hybridization with closely related native species (Ellstrand and Schierenbeck 2000). High propagule pressure can be achieved either through a single introduction of a large number of individuals or by frequent introductions (Lockwood et al. 2005, 2007; Kelly et al. 2006; Roman and Darling 2007; Barney and Whitlow 2008). Hybridization between an introduced and a native species, or intraspecific hybridization, may allow for genetic exchange, leading to novel genotypes that may be fitter than parental genotypes in the natural environment, thereby promoting accelerated rates of evolution and range expansion (Rhymer and Simberloff 1996; Ellstrand and Schierenbeck 2000; Facon et al. 2005; Mallet 2005; Schmeller et al. 2005; Culley and Hardiman 2009; Schierenbeck and Ellstrand 2009).

Here, we report on a biological invasion in which both of these effects are relevant, yet in a highly unusual manner. The lake frog, Pelophylax ridibundus Pallas 1771 (formerly Rana ridibunda until Frost et al. 2006; genotype RR), is native to eastern and north-eastern Europe and parts of Asia (Günther 1990), but it is successfully invading central and western Europe following human translocations (Pagano et al. 2001, 2003; Vorburger and Reyer 2003; Zeisset and Beebee 2003; Schmeller et al. 2007; Holsbeek et al. 2008). In contrast to other invasive species, the genetic material of $P$. ridibundus was already present in the invaded areas. That was possible because $P$. ridibundus produced viable bisexual hybrids with other water frogs, such as P. lessonae Camerano 1882 (R. lessonae, genotype
LL) and P. perezi (Berger 1983). These hybrids, $P$. esculentus Linnaeus 1758 (Rana esculenta, genotype RL) and P. grafi Crochet, Dubois, Ohler \& Tunner 1995 (Rana grafi, genotype RP) are assumed to have immigrated after the last glaciation (Wuerm age) from areas of sympatry between the parental species. Pelophylax esculentus is assumed to have immigrated to France from eastern Europe (Vorburger 2001a), while the immigration history of $P$. grafi remains unclear (but see Arano et al. 1994). Except for some pure hybrid populations where triploid individuals exist and reproduce (Rybacki and Berger 2001; Plötner 2005; Holsbeek et al. 2008; Christiansen and Reyer 2009; Arioli et al. 2010), P. esculentus generally occurs in mixed populations with only one of its parental species over large parts of Europe (Uzzell and Berger 1975). In the Pelophylax species group, an unusual, hemiclonal mode of reproduction termed hybridogenesis occurs (Schultz 1969). Considering the L-E system, in $P$. esculentus, the lessonae genome is usually discarded from the germ line prior to meiosis, which results in the production of functional haploid gametes containing the clonally transmitted ridibundus genome (R). Hybrids persist in that system by backcrossing with P. lessonae (e.g. Uzzell and Berger 1975; Graf and Polls Pelaz 1989). Such matings combine a sexual lessonae with a clonal ridibundus genome to form the next generation of $P$. esculentus. The equilibrium in the L-E system was recently thrown off due to introductions of water frogs from the $P$. ridibundus group originating from several countries (mainly Egypt, Turkey and Balkan region to central Europe). This resulted in a high genetic heterogeneity of the introduced frogs because substantial differences exist among taxa within the "P. ridibundus" group (Holsbeek et al. 2008; Plénet et al. 2009; Akin et al. 2010; Plötner et al. 2010). Especially in France, the expansion range has increased since the middle of the twentieth century because of repeated introductions of live water frogs (Pagano et al. 2001; Schmeller et al. 2005; but also see Plötner 2005). From an ecological point of view, introduced $P$. ridibundus populations differ from the native water frogs in that they inhabit mainly fluvial and peri-fluvial habitats characterized by renewed water with high dissolved oxygen levels, matching the poor performance of this species under hypoxic conditions (Tunner and Nopp 1979; Pagano et al. 1997; Plénet et al. 1998, 2000a, 2005). In contrast, 
the diploid hybridogen $P$. esculentus is constrained to coexist with $P$. lessonae in the L-E system, which preferentially occurs in habitats characterized by high dissolved organic carbon and by variable oxygen availability with severe hypoxic episodes (Plénet et al. 2005).

Many consequences of translocations of $P$. ridibundus in the western European water frog complex (L-E system) exist (Schmeller 2004; Holsbeek and Jooris 2010). Most importantly from a genetic aspect, $P$. ridibundus can also be formed by homotypic matings between two diploid P. esculentus individuals (Vorburger 2001c). Such newly formed $P$. ridibundus progeny are often assumed to be unviable ( $97 \%$ mortality) due to homozygosity of deleterious mutations that have accumulated in the clonally transmitted $\mathrm{R}$ genomes (Berger and Uzzell 1977; Binkert et al. 1982; Graf and Polls Pelaz 1989; Vorburger 2001a; Guex et al. 2002; Christiansen et al. 2005). However, there is evidence that these newly formed $P$. ridibundus can occasionally survive and even reach maturity, largely depending on the genetic difference between the two haploid R-genomes (e.g. Hotz et al. 1985; Berger et al. 1988; Hotz et al. 1992; Vorburger 2001c; Guex et al. 2002; Schmeller et al. 2005). The invasion of introduced $P$. ridibun$d u s$ into native L-E systems creates novel opportunities for primary hybridizations between $P$. ridibundus and $P$. lessonae, which may boost the diversity of ridibundus genomes among hybrids (Pagano et al. 2008). Consequently, the viability of newly formed $P$. ridibundus offspring is expected to increase, leading to an amplification of the $P$. ridibundus propagule pressure and thus to enhanced invasiveness (Guex et al. 2002; Vorburger and Reyer 2003, Schmeller et al. 2005). In addition to just increasing propagule pressure, newly formed $P$. ridibundus may also play a role in increasing local adaptation of the invaders. This may occur if there is occasional recombination between ridibundus and lessonae genomes in hybrids. This generally does not occur in native L-E systems (but see Mezhzherin et al. 2004; Schmeller 2004), yet it has been shown to be common in primary hybrids between introduced $P$. ridibundus and native $P$. lessonae or $P$. perezi (Uzzell et al. 1977; Pagano and Schmeller 1999; Guex et al. 2002; Vorburger and Reyer 2003;
Schmeller 2004; Schmeller et al. 2005; Som and Reyer 2006; Vorburger et al. 2009). Another relevant genetic mechanism is the introgression of lessonae mtDNA into P. ridibundus (Spolsky and Uzzell 1984; Hotz et al. 1992; Plötner et al. 2008). Because of these gene exchanges, newly formed $P$. ridibundus may be more likely to cope with ecological conditions usually favouring the indigenous water frogs, $P$. esculentus and P. lessonae.

Despite their potential importance, the consequences of newly formed individuals on the invasiveness of $P$. ridibundus are little explored so far (but see Vorburger and Reyer 2003). Therefore, we experimentally compared the larval performance of newly formed $P$. ridibundus with that of introduced $P$. ridibundus and native $P$. esculentus in situ across ponds differing in relevant ecological characteristics (i.e. P. lessonae- and P. ridibundus-typical habitats), as well as in the laboratory under standardized conditions (only comparison between the two ridibundus types). We also compared ecophysiological characteristics (i.e. tolerance to hypoxia) between introduced and newly formed $P$. ridibundus. We argue that if newly formed $P$. ridibundus perform similarly to introduced $P$. ridibundus and $P$. esculentus independent of environmental conditions, they could be considered as a novel $P$. ridibundus source increasing propagule pressure. If they outperform introduced $P$. ridibundus under lessonae-typical conditions or hypoxia, an additional role in improving the local adaptation of the $P$. ridibundus population would be supported.

\section{Materials and methods}

Study animals and taxon identification

We used tadpoles of three types: introduced $P$. ridibun$d u s$ (hereafter noted R), newly formed $P$. ridibundus $(\mathrm{N}$, produced by matings between hybridogenetic $P$. esculentus) and the hybridogen $P$. esculentus (E, produced by matings between P. esculentus and P. lessonae). The $\mathrm{R}$ clutches came from invasive $P$. ridibundus populations located near Lyon where only $P$. ridibundus adults were found (Pagano et al. 2001). In this study, we used the name $P$. ridibundus sensu lato ('marsh frogs') for all water frogs of the $P$. ridibundus superspecies. The real 
phylogenetic status of $P$. ridibundus remains complex, as it comprises several cryptic allo- and parapatric species with very similar morphology (e.g. Plötner et al. 2001). The N (R-like clutches) and E clutches were collected in ponds located near Lyon where only $P$. lessonae and P. esculentus adults were found (L-E system; Plénet and Joly, unpublished data).

Prior to the experiment, we analysed two tadpoles per clutch to distinguish between $\mathrm{R}, \mathrm{L}$ and $\mathrm{E}$ clutches using allozyme electrophoresis with the locus LDHB. LDH-B is a locus with no allelic overlap between $P$. ridibundus, $P$. lessonae, and $P$. perezi (see Uzzell and Berger 1975; Pagano et al. 1997) and with little impact from recombination events between the ridibundus and lessonae or perezi genome (Schmeller 2004 and references cited therein; Schmeller et al. 2005). This method confirmed the $R$ status of clutches sampled in pure introduced $P$. ridibundus populations. In L-E populations, allozyme electrophoresis allowed us to distinguish R-like, $\mathrm{L}$ and $\mathrm{E}$ clutches. Because only P. lessonae and P. esculentus adults were found in these studied populations (L-E system; Plénet and Joly, unpublished data), we considered the R-like clutches as the newly formed $P$. ridibundus resulting from hybrid $P$. esculentus matings (N status). Despite the absence of $P$. ridibundus in these specific ponds, the $\mathrm{R}$ hemigenomes possessed by the hybrids may well be influenced by the invasion of $P$. ridibundus in the area. They are likely to represent a mixture of genetic material present in the hybridogens prior to invasion and new genetic material that arrived with the introduction of $P$. ridibundus (see Introduction). At the end of the experiments, to confirm the $\mathrm{N}$ status, toe clips from all froglets successfully metamorphosed and preserved in 96\% ethanol were analysed with three polymorphic microsatellite loci: RICa1b5 (Garner et al. 2000), Res16 and Res17 (Zeisset et al. 2000), with sufficient polymorphism and absence of null alleles in $P$. ridibundus. We followed extraction protocols from Lalouette et al (2010), and PCR protocols from Garner et al. (2000) and Zeisset et al. (2000). The genotyping was done on a MegaBACE ${ }^{\mathrm{TM}}$ automated sequencer, and analysed using Genetic Profiler $^{\mathrm{TM}}$. From the populations used in this study, $148 \mathrm{E}$ individuals, $117 \mathrm{~N}$ individuals, and $96 \mathrm{R}$ individuals were genotyped. We used the program STRUCTURE to validate the E, N and R groups, using 3 assumed populations ( $\mathrm{E}, \mathrm{N}, \mathrm{R})$, population admixture, allele frequencies independent, burn-in length of 10,000, and run length of 100,000. All runs were replicated eight times, with $\mathrm{K}$ ranging from 2 to 7. $K=3$ groups maximised posterior probabilities. As evident in Fig. 1, very few individuals were assigned to other groups, and were most probably from mixed $\mathrm{E}$ and $\mathrm{N}$ broods (no wrong assignment for a priori $\mathrm{R}$ individuals).

In situ experiment

In our in situ experiment, we compared the larval performance of $\mathrm{R}, \mathrm{N}$ and $\mathrm{E}$ tadpoles in both R-typical and L-E-typical natural habitats using permeable enclosures $(60 \times 50 \times 40 \mathrm{~cm}$ polyethylene tanks; mesh $=1 \mathrm{~mm}$; for more details see Plénet et al. 2005). The two ponds used in this study were located $20 \mathrm{~km}$ apart in the same region (i.e. Rhône-Alpes region, South-Eastern France) with homogeneous climatic conditions. The R-typical habitat was a perifluvial pond in the Rhone floodplain $\left(45^{\circ} 48^{\prime}\right.$ $\left.1.3^{\prime \prime} \mathrm{N}, 4^{\circ} 53^{\prime} 14^{\prime \prime} \mathrm{E}\right)$, where water is continuously renewed by underground flow and characterised by low dissolved organic carbon and high dissolved oxygen levels (Pagano et al. 2001; Plénet and Joly, unpublished data). In contrast, the L-E-typical habitat was a pond without any fluvial influence $\left(45^{\circ} 56^{\prime}\right.$ $43.2^{\prime \prime} \mathrm{N}, 4^{\circ} 55^{\prime} 8.5^{\prime \prime} \mathrm{E}$ ), characterised by a silted bottom, high dissolved organic carbon levels and variable oxygen concentrations close to normoxia (Plénet and Joly, unpublished data). It is exclusively inhabited by L-E mixed populations. The tadpoles used in the
Fig. 1 STRUCTURE summary plot of estimates of a posteriori probability of assignment to the original group. Each bar represents one individual

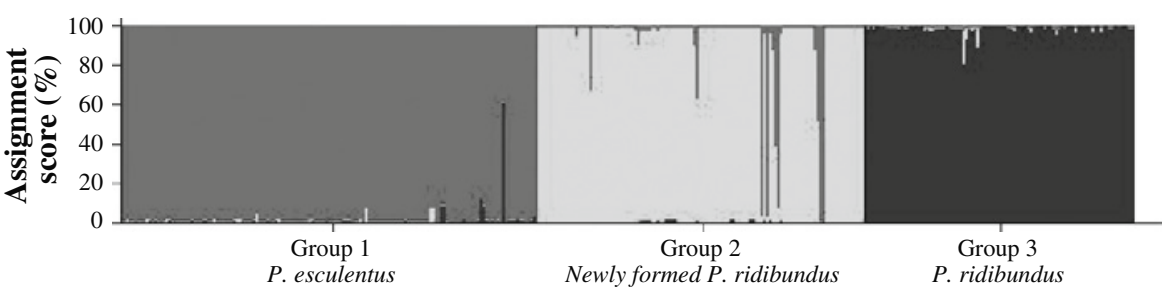


experiment were not collected at these experimental sites to avoid confounding effects due to local adaptation.

For every tadpole type (R, N, and E), we collected 10 freshly laid clutches from two source populations (5 clutches per population) on the same day. The clutches were maintained individually in nursery tanks in the laboratory under standardized conditions. When tadpoles reached the same developmental stage (Gosner stage 25, Gosner 1960), we mixed four tadpoles originating from five clutches from each source population and each tadpole type, to form six different groups of 20 individuals. These six groups were replicated three times per pond. The 36 groups of 20 tadpoles were placed in enclosures in the R-typical and the L-E-typical ponds (18 groups per pond). Groups of tadpoles were assigned randomly to enclosures within ponds. The enclosures were positioned in the ponds so that they received equal amounts of sunlight and experienced similar physical conditions (distance to the shore and to vegetation). They were floating so that water depth was maintained at $20 \mathrm{~cm}$ (approximately $54 \mathrm{~L}$ volume) throughout the experiment. The enclosures were stocked on 3 June 2004 and checked every 2 days thereafter until 15th September 2004. When tadpoles had both forelegs (i.e. Gosner stage 42-43), they were removed from enclosures and reared individually in the laboratory until the end of metamorphosis, i.e. until tail resorption was complete (stage 46). The experiment was ended when only few non-metamorphosed tadpoles remained in the enclosures. We determined several measures of larval performance: survival (the proportion of individuals surviving until the end of the experiment, including tadpoles that had not yet metamorphosed), metamorphosis success (the proportion of survivors that successfully completed metamorphosis), larval period (time from the start of the experiment until completion of metamorphosis), and two estimates of froglet body size: wet body mass and snout-to-vent length.

\section{Laboratory experiment}

In our laboratory experiment, we compared the larval performance of $\mathrm{N}$ and $\mathrm{R}$ tadpoles under benign laboratory conditions. As in the in situ experiment, $\mathrm{N}$ and $\mathrm{R}$ tadpoles came from several clutches from the same two source populations ( $\mathrm{N}$ individuals from two to five clutches, $\mathrm{R}$ tadpoles from four to five clutches per population). We reared $100 \mathrm{~N}$ and $100 \mathrm{R}$ tadpoles individually (50 tadpoles per source population per tadpole type). We randomly selected between 10 and 25 tadpoles per clutch. In early June 2006, when tadpoles had reached stage 25 , they were placed individually in boxes (12 cm diameter) filled with $1 \mathrm{~L}$ of tap water. These boxes were randomly distributed in a room that was maintained at $23^{\circ} \mathrm{C}\left( \pm 1^{\circ} \mathrm{C}\right)$ and with a 14:10 h light-dark cycle. We fed tadpoles with boiled lettuce ad libitum every day and changed the water in each box every 2 days. When tadpoles reached stage $42-43$, they were reared individually in a terrarium until the end of metamorphosis (stage 46). The experiment was terminated on 15th September 2006 when only few tadpoles had not yet entered metamorphosis. We took measurements of larval performance twice during their development. At mid development (41 days), we measured total length (to the nearest $0.1 \mathrm{~mm}$ using a binocular equipped with an ocular micrometer), wet body mass (to the nearest $0.1 \mathrm{mg}$; tadpoles dried on filter paper), and developmental stage according to Gosner (1960). At metamorphosis, we measured the same traits as in the in situ experiment.

\section{Physiological performance experiment}

Tadpoles of introduced $P$. ridibundus are more sensitive to low dissolved oxygen levels than tadpoles of native $P$. lessonae and $P$. esculentus (i.e. higher metabolism, lower LT50 in anoxia and lower metabolic levels; Plénet et al. 2000a). Consequently, $P$. ridibundus occurs mainly in habitats characterised by high oxygen availability and the absence of hypoxic episodes. In order to determine the abilities of $\mathrm{N}$ tadpoles to successfully develop in hypoxic habitats, we compared physiological performances of $\mathrm{N}$ and $\mathrm{R}$ tadpoles. We measured the individual standard metabolic rate (rates of oxygen consumption $\mathrm{VO}_{2}$ ), individual lethal time in anoxia and individual metabolite contents of tadpoles (glycogen stored under hypoxic episodes, triglycerids and proteins stored under trophic constraints) using established methods described by Hervant et al. (1995) and Plénet et al. (2000a). Sample sizes varied among assays and were between 10 and 26 individuals per type ( $\mathrm{N}$ or $\mathrm{R}$ ) and population. The tadpoles originated from the same clutches as those used in the laboratory 
experiment. However, they were reared in groups (mixing several clutches) until they reached developmental stage 37-38 (i.e. beginning of metamorphosis). After the metabolic assays, each tadpole was measured (total length), staged, and weighed (wet body mass).

\section{Statistical analyses}

We performed linear mixed model analyses of variance (ANOVAs Type III) for larval period and mass at metamorphosis of tadpoles from the in situ experiment using the nlme library version 3.1-79 (Pinheiro and Bates 2000) in the software R 2.6.0 (R Development Core Team 2007) to compare larval performance between $\mathrm{R}, \mathrm{N}$ and $\mathrm{E}$ tadpoles, accounting for variation among habitats, populations and enclosures. To remove overall size effects on mass, we used the residuals of a $\log -\log$ regression of mass at metamorphosis on snout-to-vent length. Sizecorrected mass is an interesting fitness correlate reflecting individual body condition. Habitat and tadpole type were considered fixed effects. Because only two populations per type were used, population was also treated as a fixed effect, nested within tadpole type (Snijders 2005). Enclosure was considered a random effect. We tested for the effects of habitat, tadpole type, and population, as well as for the habitat $\times$ type interaction and the habitat $\times$ population (type) interaction. The unit of observation for statistical analyses was the mean value of all individual tadpoles within an enclosure. When the condition of homogeneity of variances was not fulfilled, we specified the lme function from the nlme library to account for heteroscedasticity in the within-group errors (Pinheiro and Bates 2000).

Survival and metamorphosis success were analysed with a generalized linear model using the logit link and a binomial error distribution. For this, we used the function glmmPQL (MASS library) in R. The model included the same fixed and random effects and interactions as the ANOVAs for larval period and mass at metamorphosis.

For our laboratory experiments, the statistical analyses were similar to those previously described. We performed mixed model ANOVAs (Type III) to compare larval stage, larval period, tadpole mass at mid development and at metamorphosis between $\mathrm{N}$ and $\mathrm{R}$ tadpoles. Tadpole mass at mid development and at metamorphosis were again size-corrected, and we allowed for heterogeneity of variance in our models. Analyses to test differences in survival and metamorphosis success between the two types of $P$. ridibundus were conducted using a generalized linear mixed model. Tadpole type and population were considered fixed effects, clutch was a random effect nested within population.

Finally, the physiological performances of tadpole types and populations (nested within type) were analysed on the basis of the three physiological variables $\left(\mathrm{VO}_{2}\right.$, lethal time in anoxia, and metabolite content) by nested ANOVAs.

\section{Results}

In our in situ experiment, survival of $\mathrm{R}, \mathrm{N}$ and $\mathrm{E}$ tadpoles was similar $\left(F_{2,22}=1.897, P=0.174\right)$, and survival was similar between populations $\left(F_{6}\right.$, $22=1.609, P=0.192)$. However, survival of $\mathrm{R}, \mathrm{N}$ and $\mathrm{E}$ tadpoles differed strongly between habitats $\left(F_{1}\right.$, $\left.{ }_{22}=74.571, P<0.001\right)$. In the habitat typical of native L-E populations, survival was high for all tadpoles ( $>80 \%$; Table 1$)$ whereas it was low for all tadpoles in the R-typical habitat $(<50 \%$; Table 1$)$.

Metamorphosis success was $100 \%$ for all types of tadpoles in the L-E-typical habitat and was significantly higher than in the R-typical habitat (Table 1). Interestingly, a higher proportion of $\mathrm{E}$ tadpoles metamorphosed successfully in enclosures of the R-typical habitat than either R tadpoles $(t=15.074$, $\mathrm{df}=22, \quad P<0.001)$ or $\mathrm{N}$ tadpoles $(t=14.078$, df $=22, P<0.001)$. This resulted in a significant main effect of tadpole type $\left(F_{2}, \quad 22=\right.$ 165.644, $P<0.001)$ as well as a significant type $\times$ habitat interaction $\left(F_{2}, \quad 22=3.822, \quad P=\right.$ 0.037), and a population effect at the threshold of significance $\left(F_{6,22}=2.538, P=0.051\right)$.

Table 1 Survival and metamorphosis success of the three tadpole types in both habitats

\begin{tabular}{llllll}
\hline & \multicolumn{2}{l}{ Survival (\%) } & & \multicolumn{2}{c}{ Metamorphosis success (\%) } \\
\cline { 2 - 3 } \cline { 5 - 6 } Types & R-typical & L-E-typical & & R-typical & L-E-typical \\
\hline $\mathrm{R}$ & $41 \pm 23.7$ & $92 \pm 9.8$ & & $82 \pm 22$ & 100 \\
$\mathrm{~N}$ & $34 \pm 10.8$ & $87 \pm 12$ & & $76 \pm 23$ & 100 \\
$\mathrm{E}$ & $56 \pm 23.5$ & $91 \pm 9.7$ & & $91 \pm 6$ & 100 \\
\hline
\end{tabular}

Values are means of enclosures $\pm 1 \mathrm{SE}$ 
Our tadpole performance analysis showed no difference in size-corrected mass between tadpole types and populations (Table 2; Fig. 2). However, size-corrected mass differed significantly among habitats according to tadpole type (significant interaction, Table 2; Fig. 2). The uncorrected mass of $\mathrm{R}$ and $\mathrm{N}$ tadpoles reared in the R-typical habitat was three times lower and the snout-vent length about 1.5 times lower than that of tadpoles reared in the L-Etypical habitat. Performance differences between habitats were smaller in E tadpoles.

The effect of the habitat on larval period differed strongly between tadpole types (Table 2; Fig. 2). While for $\mathrm{R}$ and $\mathrm{E}$ tadpoles, the larval period was almost 2 weeks shorter in the L-E-typical habitat compared to the R-typical habitat, $\mathrm{N}$ tadpoles took approximately 1 week longer to develop in the L-E-typical habitat than in the R-typical habitat. This resulted in a significant main effect of tadpole type, as well as a significant type $\times$ habitat interaction (Table 2 ). In the R-typical habitat, larval period of $\mathrm{N}$ was significantly shorter relative to that of $\mathrm{E}(t=18.076, \mathrm{df}=22, P<0.001)$ and of $\mathrm{R}(t=14.041, \mathrm{df}=22, P=0.004)$. Conversely, in the L-E-typical habitat, larval period of $\mathrm{N}$ was longer relative to that of $\mathrm{E}(t=-8.952, \mathrm{df}=22$, $P<0.001)$ and of $\mathrm{R}(t=-7.326, \mathrm{df}=22, P=$

Table 2 Mixed-model nested ANOVAs (Type III) for body mass at metamorphosis (using the residuals of a regression performed on logarithm of body mass versus the logarithm of the length interpreted as a measure of size) and larval period (days from the start of the experiment until completion of metamorphosis) of tadpoles reared in the in situ experiment

\begin{tabular}{llrr}
\hline Source & Num. df, Den. df & $F$ value & \multicolumn{1}{l}{$P$} \\
\hline Body mass & & & \\
Intercept & 1,396 & 0.002 & 0.959 \\
Habitat & 1,22 & 0.492 & 0.490 \\
Type & 2,22 & 2.448 & 0.109 \\
Habitat $\times$ Type & 2,22 & 3.729 & 0.040 \\
Habitat $\times$ Pop(Type) & 6,22 & 2.072 & 0.098 \\
Larval period & & & \\
Intercept & 1,396 & 560.763 & $<0.001$ \\
Habitat & 1,22 & 11.220 & 0.003 \\
Type & 2,22 & 4.122 & 0.030 \\
Habitat $\times$ Type & 2,22 & 11.175 & $<0.001$ \\
Habitat $\times$ Pop(Type) & 6,22 & 1.527 & 0.216 \\
\hline
\end{tabular}

The random enclosure effect are not shown
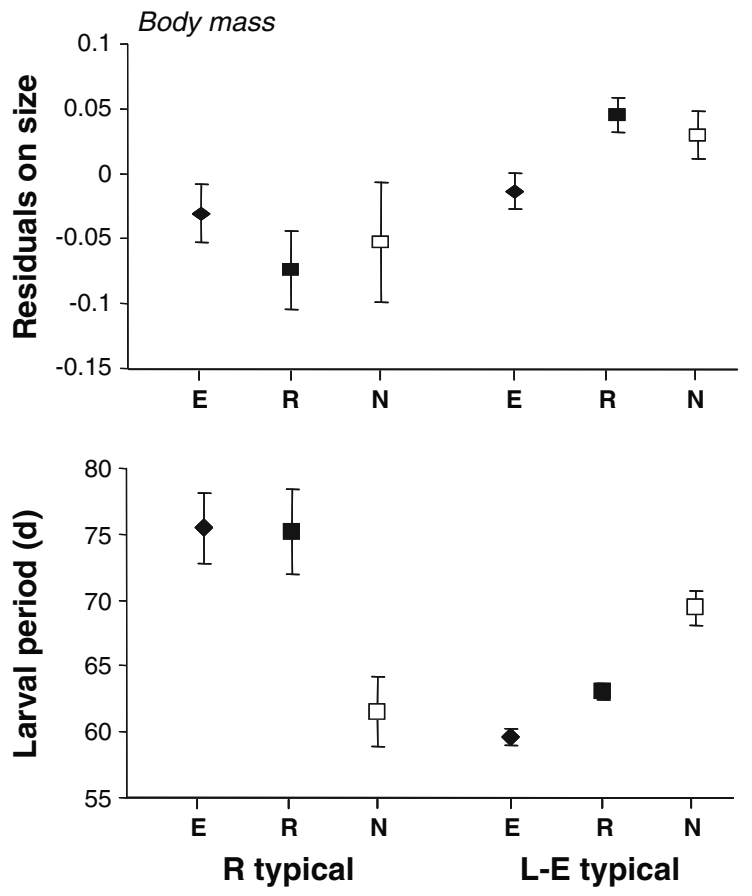

Fig. 2 Body mass corrected on size and larval period of three tadpole types reared in R-typical and L-E-typical habitats. E denotes the hybrid $P$. esculentus, $\mathrm{R}$ the introduced $P$. ridibundus, and $\mathrm{N}$ the newly formed $P$. ridibundus. Values are means of enclosures and errors bars depict $\pm 1 \mathrm{SE}$

0.003). The population effect was not significant (Table 2).

In our laboratory experiment, all tadpoles survived until mid-development (41 days), but fewer $\mathrm{N}$ than $\mathrm{R}$ tadpoles survived until the onset of metamorphosis $\left(61 \pm 25 \%\right.$ and $98 \pm 3.5 \%$ respectively; $F_{1}$, $12=8.424, P=0.013)$. The metamorphosis success was high and not significantly different for the two types of $P$. ridibundus tadpoles $(\mathrm{N}: 86 \pm 38 \%$, R: $\left.100 \% ; F_{1,12}=1.446, P=0.252\right)$.

Despite significant variation between populations within tadpole types, size-corrected mass of $\mathrm{N}$ individuals (tadpoles or metamorphs) was slightly (tadpoles) or substantially (metamorphs) larger than that of $\mathrm{R}$ individuals (Table 3; Fig. 3). Developmental stage of tadpoles at mid-development and larval period differed strongly between populations within types (Table 3). Larval period also differed among types of tadpoles with a shorter larval period for $\mathrm{N}$ than for $\mathrm{R}$ individuals (Table 3; Fig. 3). These results suggest that for most of the measured traits (except 
Table 3 Mixed-model nested ANOVAS (Type III) for body mass and larval stage of tadpoles at mid-development, body mass and larval period at metamorphosis in the laboratory experiment

\begin{tabular}{|c|c|c|c|}
\hline Source & Num. df, Den. df & $F$ value & $P$ \\
\hline \multicolumn{4}{|c|}{ Mid-development } \\
\hline \multicolumn{4}{|l|}{ Body mass } \\
\hline Intercept & 1,175 & 19.368 & $<0.001$ \\
\hline Type & 1,12 & 11.939 & 0.005 \\
\hline Pop(Type) & 2,12 & 11.416 & 0.002 \\
\hline \multicolumn{4}{|l|}{ Stage } \\
\hline Intercept & 1,175 & 19083.98 & $<0.001$ \\
\hline Type & 1,12 & 0.759 & 0.401 \\
\hline Pop(Type) & 2,12 & 5.940 & 0.016 \\
\hline \multicolumn{4}{|c|}{ Metamorphosis } \\
\hline \multicolumn{4}{|l|}{ Body mass } \\
\hline Intercept & 1,145 & 13.327 & $<0.001$ \\
\hline Type & 1,11 & 13.020 & 0.004 \\
\hline Pop(Type) & 2,11 & 1.878 & 0.199 \\
\hline \multicolumn{4}{|l|}{ Larval period } \\
\hline Intercept & 1,145 & 1635.72 & $<0.001$ \\
\hline Type & 1,11 & 5.649 & 0.037 \\
\hline Pop(Type) & 2,11 & 15.033 & 0.001 \\
\hline
\end{tabular}

Body mass was corrected for size as in Table 2. The random clutch effect are not shown

for developmental stage), $\mathrm{N}$ tadpoles can outperform $\mathrm{R}$ tadpoles.

The physiological parameters, metabolic rate $\left(F_{1}\right.$, $100=0.697, P=0.406)$, lethal time in anoxia $\left(F_{1}\right.$ $\left.{ }_{.58}=1.037, P=0.313\right)$, and metabolite contents (glycogen, protein and triglycerid; $F_{1,32}=0.891$, $P=0.352 ; \quad F_{1}, \quad 34=1.518, \quad P=0.226 ; \quad F_{1}$, ${ }_{62}=0.300, P=0.586$, respectively) did not differ significantly between $\mathrm{N}$ and $\mathrm{R}$ tadpoles (Fig. 4). There was, however, significant variation between populations within tadpole types for lethal time in anoxia $\left(F_{2,58}=4.838, P=0.011\right)$ and triglycerid content $\left(F_{2,62}=10.34, P \leq 0.001\right)$.

\section{Discussion}

We hypothesized that hybridization and hybridogenesis may increase the invasiveness of the introduced water frog $P$. ridibundus in two ways: (1) by increasing propagule pressure through the formation of viable $P$. ridibundus individuals from homotypic matings among hybrid $P$. esculentus, or (2) by increasing adaptation of the invader to the native water frogs' habitat through providing hybrid-derived ridibundus genomes that are locally adapted. While our finding that $\mathrm{N}$ tadpoles were viable and comparatively fit supports the first hypothesis, we do not find any support for the second hypothesis. $\mathrm{N}$ tadpoles did not differ from $\mathrm{R}$ tadpoles in their physiological tolerances, nor did they outperform $\mathrm{R}$ tadpoles in the native water frogs' habitat. However, shifts in the relative performance of the tadpole types across different environments support ecological constraints on the invasion of $P$. ridibundus. We discuss each of these three aspects in turn.

Hybridization and propagule pressure

The invasiveness of an introduced species is enhanced by a high propagule pressure, be it through single introductions of a large number of individuals or through frequent introductions (Lockwood et al. 2005; Kelly et al. 2006; Roman and Darling 2007; Barney and Whitlow 2008). Our study provides evidence for another peculiar way to increase propagule pressure that is a consequence of hybridogenesis. Homotypic matings among $P$. esculentus hybrids produce nonhybrid individuals of the introduced species $P$. ridibundus. How important this mechanism is as a source of $P$. ridibundus hinges on the viability and performance of such newly formed $P$. ridibundus. Indeed, their evolutionary fate is arguable. Within populations, $P$. esculentus $\times P$. esculentus matings often produce inviable offspring, owing to homozygosity for recessive deleterious mutations (Berger and Uzzell 1977; Binkert et al. 1982; Graf and Polls Pelaz 1989; Vorburger 2001a; Guex et al. 2002; Christiansen et al. 2005). However, several studies found such offspring to be viable and to reach maturity under favorable environmental conditions (all female offspring; Hotz et al. 1985, 1992; Berger et al. 1988; Vorburger 2001c; Guex et al. 2002; Vorburger and Reyer 2003). In these studies, metamorphosed female RR froglets and sexually mature RR females from hybrid $\times$ hybrid matings were observed in Swiss populations. Our results concur with these last studies. The newly formed $P$. ridibundus from within-population matings among hybrids survived and metamorphosed at rates largely higher $(>70 \%)$ than expected based on some rates suggested in the literature (i.e. 3\%; Guex et al. 

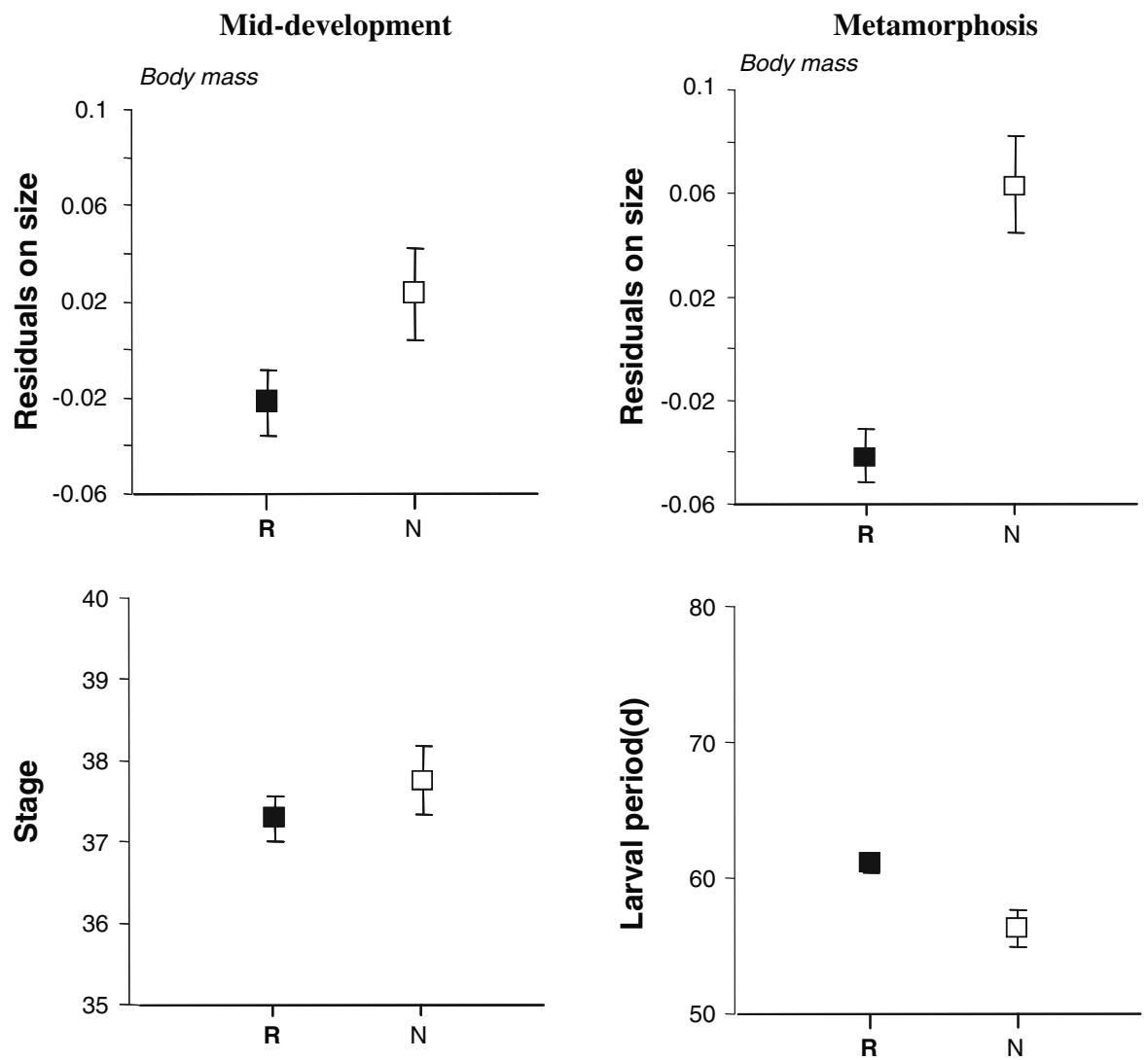

Fig. 3 Body mass corrected on size and larval stage according to Gosner (1960) at mid-development; body mass and larval period at metamorphosis of both $P$. ridibundus types in laboratory conditions. Values are means of clutches and errors bars depict $\pm 1 \mathrm{SE}$

2002; but see Schmeller et al. 2005). Moreover, N tadpoles were similar in viability and performance to "normal" $P$. ridibundus and native $P$. esculentus tadpoles under field conditions. Under laboratory conditions, survival of newly formed $P$. ridibundus tadpoles was slightly but significantly lower than that of introduced $P$. ridibundus. On the other hand, the survivors metamorphosed earlier and with a better body condition than tadpoles of introduced $P$. ridibundus. Even if only the tadpole performance until metamorphosis was considered in our study, there is evidence that larval or metamorphic traits do translate into fitness differences in the terrestrial life stage of frogs (i.e. carry over effects; Räsänen et al. 2003). Indeed, in anurans, early metamorphosis and large metamorph size enhance fitness by translating into higher juvenile survival and earlier maturity (Smith 1987; Berven 1990; Altwegg and Reyer 2003), suggesting that newly formed $P$. ridibundus should be quite competitive at postmetamorphic stages.
Another important aspect of the introduction of $P$. ridibundus is that backrosses between the hybrid and the introduced species as well as matings between newly formed and introduced $P$. ridibundus generate offspring that possess one clonal and one sexual R-genome. The limited evidence available suggests that such offspring are just as fit as sexually produced offspring from $\mathrm{R} \times \mathrm{R}$ crosses (Vorburger 2001b), and may therefore contribute to the invasive potential of the introduced water frog $P$. ridibundus. However to estimate the full contribution of this process, additional crossings such as $\mathrm{R} \times \mathrm{E}, \mathrm{N} \times \mathrm{R}$ or $\mathrm{N} \times \mathrm{E}$ would be necessary.

Finally, this relatively bright picture of the prospects for $P$. ridibundus produced by homotypic matings among hybrids has to be moderated. The $\mathrm{N}$ clutches we used in the experiment came from a larger collection of clutches of which $80 \%$ did not hatch (Luquet and Plénet, pers. obs.). It is not impossible that these aborted clutches represented 

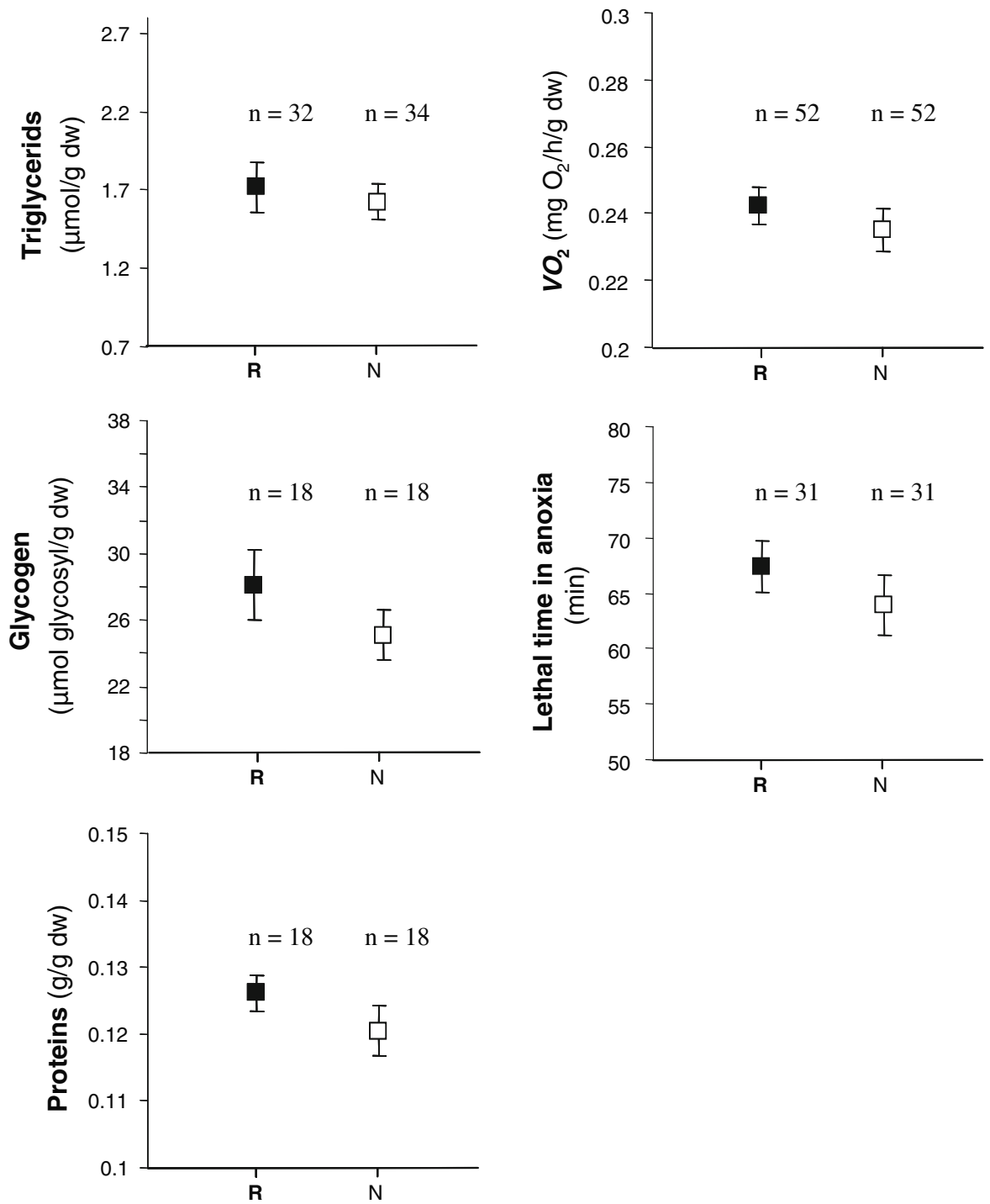

Fig. 4 Metabolic contents (triglycerids, glycogen and protein contents), rates of oxygen consumption $\left(\mathrm{VO}_{2}\right)$, and lethal time in anoxia of both $P$. ridibundus types. $n=$ numbers of individuals. Values are means and errors bars depict $\pm 1 \mathrm{SE}$

unviable hybrid $\times$ hybrid matings. Yet this does not negate the fact that a substantial fraction of such matings produces seemingly fit $P$. ridibundus that can contribute to the propagule pressure of this introduced species. Here, one needs also to keep in mind that water frog females can lay several thousands of eggs.

Hybridization and local adaptation

Hybridization and hybridogenesis may further enhance invasiveness of $P$. ridibundus by improving the local adaptation of the $P$. ridibundus populations. That is because ridibundus genomes present in hybrids are exposed to selection in L-E-typical habitat, and because of the potential gene exchanges between the different taxa of the water frog complex and their effect on offspring fitness and their ecology (Schmeller 2004). Episodic recombination between ridibundus and lessonae genomes occurs in hybrids (Uzzell et al. 1977; Pagano and Schmeller 1999; Guex et al. 2002; Vorburger and Reyer 2003; Mezhzherin et al. 2004; Schmeller 2004; Schmeller et al. 2005; Som and Reyer 2006; Vorburger et al. 
2009). Recombination in hybrids, even if rare, could entail that ridibundus genomes present in hybrids are better adapted to the ecological conditions typical for native water frogs than ridibundus genomes of introduced populations (Schmeller et al. 2005). Moreover, introgression of lessonae mtDNA in hybrid lineages may result from occasional successful matings between hybrid males and LL females. Subsequent mating between $P$. esculentus females with lessonae mtDNA and P. esculentus (or P. ridibundus) males lead to $P$. ridibundus progeny with lessonae mtDNA (Spolsky and Uzzell 1984; Hotz et al. 1992; Plötner et al. 2008). That introgressed lessonae mtDNA genomes may also provide an adaptive advantage to $P$. ridibundus, and perhaps to the hybrid individuals, is a possibility worth investigating (Plötner et al. 2008).

At our study sites in the Rhone floodplain, adults of introduced $P$. ridibundus inhabit and reproduce in habitats that are connected to freshwater sources (brooks, rivers, freshwater channels) and are characterized by relevant ecological variables such as high oxygen availability or low salinity (Pagano et al. 1997; Plénet et al. 1998, 2005; Plénet and Joly, unpublished data). These sites differ substantially in their ecological characteristics from typical habitats of the native water frogs, which frequently experience severe hypoxia (Pagano et al. 1997; Plénet et al. 2005; Plénet and Joly, unpublished data) matching the higher tolerance of native water frogs to such conditions (Plénet et al. 2000a). Indeed, under reduced oxygen availability, larvae of $P$. lessonae developed better than $P$. ridibundus larvae (Plénet et al. 2000a, b) and the survival time of LL metamorphs was higher than that of RR metamorphs (Tunner and Nopp 1979; Lutschinger 1988). All these results demonstrate that $P$. ridibundus is more sensitive to oxygen deficiency than $P$. lessonae. Consequently, to be successful in $P$. lessonae/P. esculentus habitats, tadpoles must be adapted to lowoxygen availability by exhibiting a low metabolism, high LT50 to anoxic conditions and high energetic metabolite content (Plénet et al. 2000a, b). Based on this, we expected $\mathrm{N}$ tadpoles to be less sensitive to oxygen deficiency and to exhibit physiological performances that exceed those of $\mathrm{R}$ tadpoles (i.e. lower metabolic rate, higher glycogen rate, higher LT50). However, our results provide no evidence for such an effect. Physiological performance and tolerance of anoxia of newly formed and introduced $P$. ridibundus tadpoles were very similar. Thus, newly formed $P$. ridibundus are expected to be as sensitive to hypoxic episodes as introduced $P$. ridibundus. Similarly, the in situ experiment revealed that $\mathrm{N}$ tadpoles did not outperform $\mathrm{R}$ tadpoles in the L-E-typical habitat. $\mathrm{N}$ tadpoles reached similar body mass at metamorphosis but grew slower than $\mathrm{R}$ tadpoles, indicating that they are not better adapted to the ecological conditions in the native water frogs' habitat.

\section{Ecological constraints}

Based on the hypothesis of ecological constraints on the invasion of $P$. ridibundus, we expected $\mathrm{R}$ tadpoles to perform better in the R-typical habitat but worse in the L-E-typical habitat than the native $P$. esculentus tadpoles. However, this is not what we observed in our in situ experiment. $\mathrm{R}$ tadpoles performed just as well as $\mathrm{E}$ tadpoles in enclosures in the R-typical habitat, which-based on high mortality and small size of surviving metamorphs-represented the harsher of the two environments for any tadpole type. Clearly, the R-typical habitat was much less productive, which was also evident from the lack of algal growth in these enclosures (Luquet and Plénet, pers. obs.). Considering that stressful environments are thought to amplify differences between genotypes and to exacerbate the negative effects of deleterious mutation accumulation (Kondrashov and Houle 1994; Shabalina et al. 1997; Hedrick and Kalinowski 2000; Szafraniec et al. 2001), it was surprising that in terms of development time, $\mathrm{N}$ tadpoles performed best of all three types in the R-typical habitat. Our finding confirms that tadpoles from hybrid $\times$ hybrid crosses can be comparably fit. However, an astonishing pattern emerged from the analysis of development time in the more productive L-E-typical habitat. In contrast to $\mathrm{E}$ and $\mathrm{R}$ tadpoles, which both had a shorter development time in the L-E-typical habitat, $\mathrm{N}$ tadpoles needed more time to complete metamorphosis (Fig. 2). We presently lack a satisfying explanation for this interesting habitat $\times$ tadpole type interaction.

That the larval performance of $P$. ridibundus was comparable to native species in enclosures of the L-E-typical pond suggests a high invasiveness of this species in such habitats. However, by using just a single L-E-typical pond, we did not cover the whole 
range of ecological conditions used by native water frogs. The ecological conditions in our study pond clearly were not at the tolerance limit for $P$. ridibundus tadpoles. Mixed L-E populations are known to occur in habitats that are much more extreme than the one tested here, especially in terms of oxygen availability (i.e. severe hypoxia; Pagano et al. 1997; Plénet et al. 2005; Plénet and Joly, unpublished data). Thus, the ability of $P$. ridibundus to successfully invade all the habitats of autochtonous $P$. esculentus and $P$. lessonae depends on their physiological performances. Previous studies (Tunner and Nopp 1979; Plénet et al. 2000a, b) have concluded that because of a high metabolism, a low LT50 to anoxic conditions and low energetic metabolite contents, the introduced $P$. ridibundus were too sensitive to tolerate the ecological conditions of more extreme L-E habitats and that its tadpoles cannot develop successfully under such conditions. Similar physiological performances between introduced $P$. ridibundus tadpoles and $P$. ridibundus tadpoles resulting from matings among $P$. esculentus may suggest ecological constraints to the invasion of both $P$. ridibundus types at least in some habitat types, as also indicated by the distribution of $P$. ridibundus in the lower Rhone floodplanes (Schmeller et al. 2007).

\section{Conclusion}

In addition to the spread of ridibundus-like frogs in Europe promoted by a high variability and ecological factors, our study suggests that the genetic mechanism of hybridogenesis contributes to the invasion success of the introduced water frog $P$. ridibundus. To consolidate this hypothesis, it would be appropriate to test it using a larger number of ponds per typology and to cover the whole range of the L-E-typical habitat of native frogs in a large scale experimental set up. The hybridogenetic hybrid $P$. esculentus is not just an evolutionary "dead end" for clonal ridibundus genomes (Milinski 1994). Hybrids can enhance the invasive potential of $P$. ridibundus because a notable fraction of $P$. esculentus $\times P$. esculentus matings within L-E populations produces viable and competitive $P$. ridibundus offspring. Therefore, newly formed $P$. ridibundus may be a significant source of $P$. ridibundus and should be considered in future studies on $P$. ridibundus invasiveness. Our findings agree with the model developed by Vorburger and Reyer (2003) on the expected dynamics of such a genetically driven species replacement; pure $P$. ridibundus populations are an almost inevitable outcome under ecological conditions suitable for $P$. ridibundus. However, introduced as well as newly formed $P$. ridibundus could be similarly limited to habitats without the occurrence of hypoxic episodes. To confirm these last points, testing and comparing R, $\mathrm{N}, \mathrm{E}$ and $\mathrm{L}$ tadpole performance using a larger number of ponds per typology and increasing the range of L-E-typical habitats would be appropriate. For the conservation of native water frogs, our results are reassuring. Some habitats may function as refuge environments for the autochthonous species. However, we cannot exclude that future genetic exchanges between ridibundus and lessonae genomes and natural selection processes will eventually allow $P$. ridibundus to invade new habitats.

Acknowledgments We thank S. Kosellek and J. Cote for their help with field and laboratory works, as well as $\mathrm{M}$. C. Fisher and D. C. Woodhams for linguistic corrections. Constructive comments on the manuscript were provided by an anonymous reviewer. This study was made possible by partnerships with Fondation Pierre Vérots (Saint-Jean-deThurigneux, Ain, France) and pumping site (Zone de captage "Crépieux-Charmy", Villeurbanne, France) and was supported by grants from French Environment Ministry (program INVABIO).

\section{References}

Akin C, Bilgin CC, Beerli P, Westaway R, Ohst T, Litvinchuk SN, Uzzell T, Bilgin M, Hotz H, Guex GD, Plotner J (2010) Phylogeographic patterns of genetic diversity in eastern Mediterranean water frogs were determined by geological processes and climate change in the Late Cenozoic. J Biogeogr 37:2111-2124

Alpert P, Bone E, Holzapfel C (2000) Invasiveness, invasibility and the role of environmental stress in the spread of nonnative plants. Perspect Plant Ecol Evol Syst 3:52-66

Altwegg R, Reyer HU (2003) Patterns of natural selection on size at metamorphosis in water frogs. Evolution 57:872-882

Arano B, Llorente GA, Herrero P, Sanchiz B (1994) Current studies on Iberian water frogs. Zoologica Poloniae 39:365-375

Arioli M, Jakob C, Reyer HU (2010) Genetic diversity in water frog hybrids (Pelophylax esculentus) varies with population structure and geographic location. Mol Ecol 19:1814-1828

Barney JN, Whitlow TH (2008) A unifying framework for biological invasions: the state factor model. Biol Invasions 10:259-272 
Berger L (1983) Western Palearctic water frogs (Amphibia, Ranidae): systematics, genetics and population compositions. Experientia 39:27-130

Berger L, Uzzell T (1977) Vitality and growth of progeny from different egg size classes of Rana esculenta L. (Amphibia, Salientia). Zoologica Poloniae pp 291-317

Berger L, Uzzell T, Hotz H (1988) Sex determination and sex ratios in western Palearctic water frogs: $\mathrm{XX}$ and $\mathrm{XY}$ female hybrids in the Pannonian Basin? Proc Acad Nat Sci Phila 140:220-239

Berven KA (1990) Factors Affecting Population Fluctuations in Larval and Adult Stages of the Wood Frog (Rana Sylvatica). Ecology 71:1599-1608

Binkert J, Borner P, Chen PS (1982) Rana esculenta complexan experimental-analysis of lethality and hybridogenesis. Experientia 38:1283-1292

Christiansen DG, Reyer HU (2009) From clonal to sexual hybrids: genetic recombination via triploids in all-hybrid populations of water frogs. Evolution 63:1754-1768

Christiansen DG, Fog K, Pedersen V, Boomsma JJ (2005) Reproduction and hybrid load in all-hybrid populations of Rana esculenta water frogs in Denmark. Evolution 59:1348-1361

Culley TM, Hardiman NA (2009) The role of intraspecific hybridization in the evolution of invasiveness: a case study of the ornemental pear tree Pyrus calleryana. Biol Invasions 11:1107-1119

Ellstrand NC, Schierenbeck KA (2000) Hybridization as a stimulus for the evolution of invasiveness in plants? Proc Natl Acad Sci USA 97:7043-7050

Facon B, Jarne P, Pointier JP, David P (2005) Hybridization and invasiveness in the freshwater snail Melanoides $t u$ berculata: hybrid vigour is more important than increase in genetic variance. J Evol Biol 18:524-535

Facon B, Genton BJ, Shykoff J, Jarne P, Estoup A, David P (2006) A general eco-evolutionary framework for understanding bioinvasions. Trends Ecol Evol 21:130-135

Frost DR, Grant T, Faivovich R, Bain RH, Haas A, Haddad CFB, De Sa RO, Channing A, Wilkinson M, Donnellan SC (2006) The amphibian tree of life. Bull Am Mus Nat Hist 297:8-370

Garner TWJ, Gautschi B, Rothlisberger S, Reyer HU (2000) A set of CA repeat microsatellite markers derived from the pool frog, Rana lessonae. Mol Ecol 9:2173-2175

Gosner KL (1960) A simplified table for staging anuran embryos and larvae with notes on identification. Herpetologica 16:183-190

Graf JD, Polls Pelaz M (1989) Evolutionary genetics of the Rana esculenta complex. In: Dawley RM, Bogart JP (eds) Evolution and ecology of unisexual vertebrates, pp 298-302, New York State Museum Bulletin 466, Albany, USA

Guex GD, Hotz H, Semlitsch RD (2002) Deleterious alleles and differential viability in progeny of natural hemiclonal frogs. Evolution 56:1036-1044

Günther R (1990) Die Wasserfrösche Europas (Anura-Froschlurche). Die Neue Brehm Bücherei, A. Ziemsen Verlag, Wittenberg Lutherstadt

Hedrick PW, Kalinowski ST (2000) Inbreeding depression in conservation biology. Annu Rev Ecol Evol Syst 31:139162
Hervant F, Mathieu J, Garin D, Fréminet A (1995) Behavioral, ventilatory and metabolic responses to severe hypoxia and subsequent recovery of the hypogean Niphargus rhenorhodanensis and the epigean Gammarus fossarum (Crustacea: Amphipoda). Physiol Zool 68:223-244

Holsbeek G, Jooris R (2010) Potential impact of genome exclusion by alien species in the hybridogenetic water frogs (Pelophylax esculentus complex). Biol Invasions 12:1-13

Holsbeek G, Mergeay J, Hotz H, Plötner J, Volckaert FAM, De Meester L (2008) A cryptic invasion within an invasion and widespread introgression in the European water frog complex: consequences of uncontrolled commercial trade and weak international legislation. Mol Ecol 17:5023-5035

Hotz H, Mancino G, Bucci-Innocenti S, Ragghianti M, Berger L, Uzzell T (1985) Rana ridibunda varies geographically in inducing clonal gametogenesis in interspecies hybrids. J Exp Zool 236:199-210

Hotz H, Beerli P, Spolsky C (1992) Mitochondrial-DNA reveals formation of nonhybrid frogs by natural matings between hemiclonal hybrids. Mol Biol Evol 9:610-620

Kelly DW, Muirhead JR, Heath DD, Macisaac HJ (2006) Contrasting patterns in genetic diversity following multiple invasions of fresh and brackish waters. Mol Ecol 15:3641-3653

Kolar CS, Lodge DM (2001) Progress in invasion biology: predicting invaders. Trends Ecol Evol 16:199-204

Kondrashov AS, Houle D (1994) Genotype-environment interactions and the estimation of the genomic mutationrate in Drosophila-melanogaster. Proc R Soc Lond B Biol Sci 258:221-227

Lalouette L, Kaufmann B, Konecny L, Renault D, Douady CJ (2010) Characterization and PCR multiplexing of 14 new polymorphic microsatellite loci for the invasive subantarctic carabid Merizodus soledadinus (Coleoptera: Carabidae). Cons Genet Resour 1:455-458

Lee CE (2002) Evolutionary genetics of invasive species. Trends Ecol Evol 17:386-391

Lockwood JL, Cassey P, Blackburn T (2005) The role of propagule pressure in explaining species invasions. Trends Ecol Evol 20:223-228

Lockwood JL, Hoopes MF, Marchetti MP (2007) Invasion ecology. Blackwell, Oxford

Lutschinger G (1988) Zur Uberwinterung der Wasserfrösche in den Donau- und Marchauen. In: Günther R, Klewen R (ed) Beiträge zur Biologie und Bibliographie (1960-1987) der europäischen Wasserfrösche, Jb. Feldherp. Beiheft 1, Verlag für Okologie u. Faunistik, Duisburg, pp. 153-160

Mallet J (2005) Hybridization as an invasion of the genorne. Trends Ecol Evol 20:229-237

Mezhzherin SV, Morozov-leonov SI, Nekrasova OD (2004) Natural transfer of nuclear genes in hybrid populations of green frogs Rana esculenta L., 1758 complex: space-time analysis of the phenomenon. Genetika 40:1646-1653

Milinski M (1994) Hybridogenetic frogs on an evolutionary dead-end road. Trends Ecol Evol 9:62

Pagano A, Schmeller DS (1999) Is recombination less negligible than previously described in hybridogenetic water frogs? In: Miaud C, Guyétant R (eds) 9th O.G. Meetingcurrent studies in herpetology. SEH, Le Bourget du Lac, France, pp 351-356 
Pagano A, Joly P, Hotz H (1997) Taxon composition and genetic variation of water frogs in the mid-Rhone floodplain. C R Acad Sci Ser III Sci Vie 320:759-766

Pagano A, Crochet PA, Graf JD, Joly P, Lode T (2001) Distribution and habitat use of water frog hybrid complexes in France. Glob Ecol Biogeogr 10:433-441

Pagano A, Dubois A, Lesbarreres D, Lode T (2003) Frog alien species: a way for genetic invasion? C R Biol 326:S85S92

Pagano A, Lesbarrères D, Crivelli A, Veith M, Lodé T, O’Hara R, Schmeller DS (2008) Geographical and ecological distributions of frog hemiclones suggest occurrence of both "General Purpose Genotype" and "Frozen Niche Variation" clones. J Zool Syst Evol Res 46:162-168

Pinheiro JC, Bates DM (2000) Mixed-effects models in S and S-PLUS. Springer, New York

Plénet S, Joly P, Pagano A (1998) Is habitat requirement by an oxygen-dependent frog (Rana ridibunda) governed by its larval stage? Arch Hydrobiol 143:107-119

Plénet S, Hervant F, Joly P (2000a) Ecology of the hybridogenetic Rana esculenta complex: differential oxygen requirements of tadpoles. Evol Ecol 14:13-23

Plénet S, Pagano A, Joly P, Fouillet P (2000b) Variation of plastic responses to oxygen availability within the hybridogenetic Rana esculenta complex. J Evol Biol 13:20-28

Plénet S, Joly P, Hervant F, Fromont E, Grolet O (2005) Are hybridogenetic complexes structured by habitat in water frogs? J Evol Biol 18:1575-1586

Plénet S, Joly P, Schmeller DS (2009) Nouvelle combinaison génétique par hybridation et accroissement du potentiel invasif, suite à une introduction. Genetic diversity of an introduced frog and ecological risks of species introduction. In: Barbault R, Atramentowiczs M (eds) Les invasions biologiques, une question de natures et de sociétés, INRA, Versailles, pp 24-25

Plötner J (2005) Die westpaläarktischen Wasserfrösche-von Märtyren der Wissenschaft zur biologischen Sensation. Laurenti-Verlag, Bielefeld

Plötner J, Ohst T, Böhme W, Schreiber R (2001) Divergence in mitochondrial DNA of Near Eastern water frogs with special reference to the systematic status of Cypriote and Anatolian populations (Anura, Ranidae). Amphib-Reptilia 22:397-412

Plötner J, Uzzell T, Beerli P, Spolsky C, Ohst T, Litvinchuk SN, Guex GD, Reyer HU, Hotz H (2008) Widespread unidirectional transfer of mitochondrial DNA: a case in western Palaearctic water frogs. J Evol Biol 21: 668-681

Plötner J, Uzzell T, Beerli P, Akin C, Bilgin CC, Haefeli C, Ohst T, Köhler F, Schreiber R, Guex G-D, Litvinchuk AN, Westaway R, Reyer H-U, Hotz H (2010) Genetic divergence and evolution of reproductive isolation in eastern Mediterranean water frogs. In: Glaubrecht M (ed) Evolution in action. Case studies in adaptive radiation and the origin of biodiversity. Special volume from the SPP 1127 "Radiations: Genesis of Biological diversity" of the DFG. Springer, Berlin, pp 373-403

Räsänen K, Laurila A, Merilä J (2003) Carry-over effects of embryonic acid conditions on development and growth of Rana temporaria tadpoles. Freshwater Biol 47:19-30
Rhymer JM, Simberloff D (1996) Extinction by hybridization and introgression. Annu Rev Ecol Syst 27:83-109

Roman J, Darling JA (2007) Paradox lost: genetic diversity and the success of aquatic invasions. Trends Ecol Evol 22:454-464

Rybacki M, Berger L (2001) Types of water frog populations (Rana esculenta complex) in Poland. Mitteilungen aus dem Museum fuer Naturkunde in Berlin Zoologische Reihe 77:51-57

Sakai AK, Allendorf FW, Holt JS, Lodge DM, Molofsky J, With KA, Baughman S, Cabin RJ, Cohen JE, Ellstrand NC, McCauley DE, O’Neil P, Parker IM, Thompson JN, Weller SG (2001) The population biology of invasive species. Annu Rev Ecol Syst 32:305-332

Schierenbeck KA, Ellstrand NC (2009) Hybridization and the evolution of invasiveness in plants and other organisms. Annual Meeting of the American-Botanical-Society, Salt Lake City, UT, pp 1093-1105

Schmeller DS (2004) Tying ecology and genetics of hemiclonally reproducing waterfrogs (Rana, Anura). Ann Zool Fenn 41:681-687

Schmeller DS, Seitz A, Crivelli A, Veith M (2005) Crossing species' range borders: interspecies gene exchange mediated by hybridogenesis. Proc R Soc Biol Sci Ser B 272:1625-1631

Schmeller DS, Pagano A, Plénet S, Veith M (2007) The population biology of invasive species. Annu Rev Ecol Syst 32:305-332

Schultz RJ (1969) Hybridization, unisexuality, and polyploidy in the teleost Poeciliopis (Poeciliidae) and other vertebrates. Am Nat 103:605-619

Shabalina SA, Yampolsky LY, Kondrashov AS (1997) Rapid decline of fitness in panmictic populations of Drosophila melanogaster maintained under relaxed natural selection. Proc Natl Acad Sci USA 94:13034-13039

Smith DC (1987) Adult recruitment in chorus frogs: effects of size and date at metamorphosis. Ecology 68:344-350

Snijders TAB (2005) Fixed and random effects. In: Everitt BS, Howell DC (eds) Encyclopedia of statistics in behavioral science, vol 2. Wiley, Chicester, pp 664-665

Som C, Reyer HU (2006) Hemiclonal reproduction slows down the Muller's ratchet in the hybridogenetic frog Rana esculenta. J Evol Biol 20:650-660

Spolsky C, Uzzell T (1984) Natural interspecies transfer of mitochondrial DNA in amphibians. Proc Natl Acad Sci USA 81:5802-5805

Suarez AV, Tsutsui ND (2008) The evolutionary consequences of biological invasions. Mol Ecol 17:351-360

Szafraniec K, Borts RH, Korona R (2001) Environmental stress and mutational load in diploid strains of the yeast Saccharomyces cerevisiae. Proc Natl Acad Sci USA 98:1107-1112

R Development Core Team (2007) R: A language and environment for statistical computing. Austria, Vienna: R foundation for statistical computing. ISBN 3-900051-07-0 (http://www.R-project.org)

Tunner HG, Nopp H (1979) Heterosis in the common European water frog. Naturwissenschaften 66:268-269

Uzzell T, Berger L (1975) Electrophoretic phenotypes of Rana ridibunda, Rana lessonae, and their hybridogenetic associate, Rana esculenta. Proc Acad Nat Sci Phila 127:13-24 
Uzzell T, Günther R, Berger L (1977) Rana ridibunda and Rana esculenta: a leaky hybridogenetic system (Amphibia Salientia). Proc Acad Nat Sci Phila 128:147-171

Vorburger C (2001a) Fixation of deleterious mutations in clonal lineages: evidence from hybridogenetic frogs. Evolution 55:2319-2332

Vorburger C (2001b) Heterozygous fitness effects of clonally transmitted genomes in waterfrogs. J Evol Biol 14:602-610

Vorburger C (2001c) Non-hybrid offspring from matings between hemiclonal hybrid waterfrogs suggest occasional recombination between clonal genomes. Ecol Lett 4: 628-636

Vorburger C, Reyer HU (2003) A genetic mechanism of species replacement in European waterfrogs? Cons Genet $4: 141-155$
Vorburger C, Schmeller DS, Hotz H, Guex GD, Reyer HU (2009) Masked damage: mutational load in hemiclonal water frogs. In: Van Dijk P, Martens K, Schoen I (eds) Lost sex - the evolutionary biology of parthenogenesis. Springer, Netherlands, pp 433-446

Zeisset I, Beebee TJC (2003) Population genetics of a successful invader: the marsh frog Rana ridibunda in Britain. Mol Ecol 12:639-646

Zeisset I, Rowe G, Beebee TJC (2000) Polymerase chain reaction primers for microsatellite loci in the north European water frogs Rana ridibunda and $R$. lessoane. Mol Ecol 9:1173-1174 